\title{
Consumer's e-signals Prism analysis: impact and implications for corporate communication strategy
}

\author{
PAOLA SignORI ILENIA CONFENTE*
}

\begin{abstract}
Purpose of the paper: Based on a conceptual framework of the updated communication process analysis, this paper seeks to test and validate new requirements and tools for brand audits in online contexts (C-Radar and Prism Analysis Table).

Methodology: This study was realized through the analysis of textual discourse in several social media, adopting an automated sentiment software crawler which downloaded texts converted them into quantitative data. The sample was related to 50 global brands of eight industries by collecting information from 19236 messages and measuring three main variables: Brand Noise, Valence and Value.

Findings: The study empirically enriches the state of the art related to communication audit by including and analysing the external messages and stimuli of online contexts.

Limitation: Although we worked to reduce limitations, some biased errors remain due to the data collection software (misinterpretation of key words, coexistence of persons/slangs/common words similar to the brand name). Another limitation, timing of the one-shot observation, has been compensated by the large sample.

Managerial implication: Through this approach, firms will understand whether to integrate e-signals within companies' communication strategies how to intervene (if needed), and how to influence the new stimuli message.

Originality of the paper: The research suggests a model for communication process analysis, including the main external consumers' messages and the tracking and understanding of the valence and noise of these messages. In addition, it allows the evaluation of their impact on corporate communication strategies related to social network environments.
\end{abstract}

Key words: communication audit; marketing strategy; web marketing; word of mouth; social networks; prism analysis.

\footnotetext{
Associato di Economia e Gestione delle Imprese - Università degli Studi di Verona e-mail: paola.signori@univr.it

** Ricercatore di Economia e Gestione delle Imprese - Università degli Studi di Verona e-mail: ilenia.confente@univr.it
} 


\section{Corporate communication process and the integration of external messages}

The main goal of the paper is to seek and validate new requirements and tools for brand audits in e-contexts ( $C$-Radar and Prism Analysis Table). This will allow the capturing of both company communication flows and external messages and stimuli.

In fact, the company communication process has to deal with other external message senders that spread other communication flows, which could have the same or a negative/enhanced effect on the planned company communication flow. From a traditional perspective (Shannon, 1948; Shannon and Weaver, 1949; Lasswell, 1948; Braddock, 1958; Weiner, 1948; 1986), the communication process distinguishes two main players, respectively the sender and the receiver. The latter, for the above authors, only receives the message and gives a feedback to the sender.

However, as already suggested by Lazarsfeld's school perspective, many receivers do not passively receive a company message, because they may also react towards other customers or the company. When receivers become active message senders, they might send a feedback or a completely new message to the firm (Foulger, 2004).

For this reason, the communication process analysis should consider the coexistence of external communication flows issued by other players, such as the receivers themselves, indirect receivers, other stakeholders or other companies' communication. Indeed, the communication between companies and consumers should actually be considered a dialogue where consumers are not only receivers but also active message senders (Prahalad and Ramaswamy, 2000).

The development of the Internet and other ICTs has enhanced the role of consumers as knowledge and information sources, promoting opportunities of interaction between them and companies at lower costs and less time (De Chiara, 2009). As suggested by several authors (Prahalad and Ramaswamy, 2000; Lau, 2001; Cova and Dalli, 2009; Belk, 2010), the dialogue between consumers and companies can be considered peer to peer communication.

From this perspective, consumers play different roles within the marketing process, actively reporting their needs to the firms but also becoming product reviewers for other potential consumers. Moreover, they may become market research partners, both in the new product development and in other marketing tactics and communication activities (O'Guinn and Muniz, 2005; Fournier, 1999; Deighton, 2002; Holt, 2004; Wipperfurth, 2005; Vescovi, 2008, 2009).

However, this collaborative consumer behaviour, often considered a positive tool, is not always supportive of the company. As a consequence, consumers' activities may share company resources (Belk, 2010) or co-create value, but also criticize such resources (Cova and Dalli, 2009). In some cases, when consumers group together, they are able to represent a powerful challenge for companies, for instance when they create critical consumer movements against some form of corporation behaviour or negligence (Cova and Dalli, 2009; Kozinets and Handelman, 2004; Kozinets et al., 2010; Hollenbeck and Zinkhan, 2010). These 
movements occur both online and offline, and their aims are to support social and environmental issues or other causes. Some companies, as senders, are trying to consider if and how to integrate these parallel communication flows, in order to act in an effective way. To conclude, companies should face the following challenges:

- whether to integrate e-signals within companies communication strategies or not; - what stimuli are needed;

- who the right target to address is(i.e. the main influencers in a community);

- calculate the total online brand noise and valence.

In particular, this study will address how to track and evaluate the amount of online comments that arise around a brand, and how to understand the valence of messages created by customers.

In doing so, the article is structured as follows: first there will be a literature background about Word of Mouth as an important source of information for customers, followed by an overview on the communication audit framework we refer to. After that, methodology, main findings, implications, limitations, and conclusions will be developed.

Despite the variety of channels a person can choose from to communicate and receive information, interpersonal communication is perceived as one of the most credible and important information sources for consumers (Buttle, 1998; Godes and Mayzlin, 2004; Schindler et al., 2005; Trusov et al., 2009), particularly in relation to perceived value, service quality and customer satisfaction (Arnould and Price 1993; Clark and Martin 1996; Bettencourt 1997; Grove and Fisk, 1997; Martin, Pranter, 1989). For these reasons, Word Of Mouth (WOM) and electronic WOM (e-WOM) could represent a communication tool managed by consumers, and therefore be perceived as more credible compared to companies communication flows (cfr. nota p. 1) (Arndt 1967; Schiffman and Kanuk, 1995; Hennig-Thurau et al., 2004). Many studies have emphasized these consumer behaviours and their influence on other consumers' perceived value (Martin and Pranter, 1989; Arnould and Price, 1993; Clark and Martin, 1996; Bettencourt, 1997; Grove and Fisk, 1997; Dellarocas, 2006; Confente, 2011; Hu et al., 2012). In addition, the Internet may enable companies to easily observe and track these conversations, thus understanding how consumers interact with each other as members of a community (Chevalier and Mayzlin, 2006; Liu, 2006; De Bruyn and Lilien, 2008; Chen and Xie, 2008; Confente, 2012).

An important aspect to highlight is that e-WOM is constituted by the number of online conversations that happen among people who do not know each other, remain anonymous, or have a nick name that differs from their real one (Dellarocas, 2003; Goldsmith and Horowitz, 2006; Sen and Lerman, 2007). As a consequence, consumers might feel free to express their true opinions about products and/or brands compared to traditional WOM (Chatterjee, 2001).

One goal of this study is to provide a better understanding of the noise surrounding a brand that is created by online communities; after that the second purpose will be to explore if these online comments are positive, negative or neutral. Finally, the ultimate aim will be to determine if the social brand reputation is related to the brand value. 


\section{The Communication Audit framework and the Prism Analysis table}

Communication audits are considered important tools within the strategic decision making process (Brownlie, 1993; Camus, 1988; Cherubini, 1988; Cugini and Wilson, 2005; Fogg 1985; Hargie and Tourish, 2000; Kotler et al,. 1977; McDonald, 1991; McDonald Leppard, 1991; Oxenfeldt, 1959; Stern, 1972; Wilson, 1982, 2002). It is important to align the goals of the communication plan with the goals of the business and demonstrate value (Goldhaber and Krivonos, 1977; Hargie and Tourish, 2000; Signori, 2008). Indeed, communication measurement is more widely recognized as a standard global practice in public relations and communication. Communication investment can be evaluated only if it has measurable indicators aligned to business goals (Hargie and Tourish, 2000).

The measure of communication effectiveness also provides meaningful information for companies. In fact, the challenge is to show business leaders how communication, which supports business goals, might enrich results and brand value over the long term (Hogard and Ellis, 2006). These evergreen concepts should be updated in the light of all the new opportunities offered by electronic contexts. New scenarios show greater communication activities "outside" the company, and business firms are now careful to include relevant measurement in their dashboards.

In a recent study, the communication audit framework was revised with the integration of external C2C signals and stimuli (Signori and Confente, 2011). Conceptually, it suggested a communication audit tool, the Communication-Radar ( $C$-Radar), that should be adopted to capture any external communication signals in order to analyze:

- the width of the signal (noise);

- the power of the signal (amount of external reactions to a company's message);

- input factors (to understand if the external signals are independent or a response to the company's message).

If the C-Radar alerts the company of the existence of external brand communication flows with a loud noise, companies should play an active role. Instead, when it registers a slight noise, managers can decide to maintain a passive control over these message sources.

Another communication audit tool, the Prism Analysis table, was presented and should be validated. It is an external communication impact analysis, which tries to evaluate the valence of external noise. This tool allows a content analysis of posts in order to understand if they modify or distort the planned company message.

The Prism Analysis table allows the company to decide whether to intervene, actively or passively, or not. To help in this decision, the Prism Analysis table has been divided into 9 areas based on two main variables: what and valence (See Figure 1).

Starting from the "valence" variable, it can be understood how the demand side receives and rebound these messages. On the other side, through a "what analysis", the Prism classifies the kind of messages coming from external sources, known as the supply side, such as online communities and social networks. 
Fig. 1: Prism Analysis table

\begin{tabular}{|c|c|c|c|}
\hline \multicolumn{2}{|c|}{ SUPPLY SIDE - WHAT } & & \\
\hline Same & Different & & \\
\hline $\begin{array}{c}\text { To send viral signals: } \\
\text { Chain integration suggested }\end{array}$ & $\begin{array}{l}\text { To capture signals: } \\
\text { Partnership } \\
\text { Indirect interference }\end{array}$ & 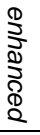 & \multirow{3}{*}{ 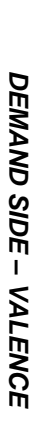 } \\
\hline $\begin{array}{l}\text { Ordinary management: } \\
\text { Focus on marketing mix }\end{array}$ & $\begin{array}{l}\text { To keep control: } \\
\text { Careful interaction }\end{array}$ & 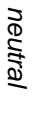 & \\
\hline $\begin{array}{c}\text { To understand mistakes: } \\
\text { General intervention is necessary No } \\
\text { interposition }\end{array}$ & $\begin{array}{c}\text { Crisis planning: } \\
\text { Intervention on main influencers } \\
\text { No integration }\end{array}$ & $\frac{\frac{2}{5}}{\frac{0}{0}} \frac{2}{\frac{1}{2}}$ & \\
\hline
\end{tabular}

Source: Our elaboration

In Figure 1, in the first column (same) there are external communication flows, which are similar in meaning to organization communication purposes. These message inputs may be independent from the company's ones, or a response to them.

In the first square on the top left (juncture between same and enhanced), firms are likely to be advised to actively stimulate viral marketing because online communities demonstrate to have correctly spread the company message and perceived it in an augmented way. In this case, when the main communication goal is awareness, the integration of consumers' communities with firm communication is advisable.

In the same column, linking the same message with neutral perception (same/neutral), companies should behave in a passive way; the suggestion is to listen to conversations, in order to include feedback in the communication audit.

Leading towards the last square of the first column (same/distorted), a deep analysis is required to understand company communication mistakes, e.g. wrong channels, wrong codes or a lack of consonance with the target. In these cases, it is important to understand these mistakes and modify the communication plan in order to reduce any differences in meaning.

Moving to the second column (different), there are external messages that have different contents compared to those sent by the company. In the first square to the top right (different/enhanced), there are active communities that are sometimes independent. The orientation should be towards interacting within communities, or creating partnership with opinion leaders, "lead members" or "evangelists" (Lee et al., 2006). Companies should stimulate conversation, thus enhancing their viral effects. 
In the middle square of the second columns (different/neutral), online communities seem to have a rather weak influence in the perception process. Here we suggest to keep control over these online stimuli and to interact carefully.

In the last square on the right bottom (different/distorted), online signals may lead to the communities boycotting the company. It is important to verify if these stimuli come from black marketing made by competitors or from actual unsatisfied consumers while paying attention not to crowd these communities. It is also important to identify main online influencers and be ready to manage a potential crisis.

To summarize, the Prism Analysis table proposes some managerial implications as a response to different external communication stimuli. This table now needs a method to correctly identify external signals and place them in the right section.

\section{Research Design and Methodology}

The main goal of this paper is to better understand the social noise surrounding a brand and its valence (demand side) in order to contribute to the corporate communication audit framework in e-contexts, and begin the validation of its tools ( $C$-Radar and one side of the Prism Analysis table).

From the previous section and related literature background, the hypotheses of this study are related to the following three different concepts:

- $\mathrm{H}_{1}$ "Noise":

A social noise (SN) around a brand is related to the total amount of web signals (WN, Web Noise) around the brand;

- $\mathrm{H}_{2}$ "Valence":

- $H_{2.1}$ The social noise about a brand is mostly constituted by positive comments (Word of Mouth) of extremely satisfied consumers/participants;

- $H_{2.1}$ The social noise about a brand is mostly constituted by negative comments (Word of Mouth or direct claims) of extremely dissatisfied consumers/participants;

- $H_{2.3}$ The neutral rebound activity (neutral posts) generates less SN (social noise) compared to the ones related to positive or negative WOM activity.

- $\mathrm{H}_{3}$ "Value":

- $H_{3.1}$ The brand's social reputation is strictly related to the brand's value;

- $\quad H_{3.2}$ The brand's value is strictly related to the brand's social reputation.

To develop the research, the methods of textual discourse observation and analysis were applied. We used a data collection method and a text mining approach through software (Miller, 2005). The conversion of textual material into quantitative data is not new in the marketing literature (Mohr and Nevin, 1990; Noble et al., 2002). 
The adoption of automated sentiment analysis was required to understand and measure the social noise and, in the meanwhile, to classify the valence of social media posts. For this reason, we needed Web crawler technology to capture and classify this sort of communication.

To do so, ten of the main online softwares for content (Lowe, 2003) and sentiment analysis were explored and tested. At the end of the software selection, Samepoint was chosen for the collection of noise data and Social Mention for sentiment analysis and valence information.

\subsection{Sample selection}

The sample selection aimed at finding brands around which there could be enough social noise and attention and with a significant amount of messages. To create a wide, multi-firm and cross-industry sample, the top 50 brands listed in the 2011SMR index (Social Media Reputation Index by Yomego), were chosen (see Appendix 1). This index ranks brands' popularity in social spaces. There are many tools to track a brand's profile across social media channels. The Social Media Reputation (SMR) score provides a benchmark to gauge brands' respective popularity. The SMR score is derived by averaging two variables: the noise around a brand (reach) and its popularity (satisfaction). Then the numbers from the last month are compared to the previous three months to apply a topical adjustment (recency).

The 50 brands with the highest social media reputation index belong to 8 main industries: Technology; Automotive; Retail; Food and drink; Online service; Entertainment; Financial; Health and beauty.

The 50 selected brands are also included in the Top 100 Global Brands, which are classified by value (Interbrand 2010; see Appendix 1).

\subsection{Data collection and analysis}

After the brands' selection, the research aimed at collecting online conversations about these brands within the most important social network sites.

Therefore, it was necessary to proceed with a content and sentiment analysis software selection in order to realize observations and analyses of textual discourses. In order to choose the most appropriate one, the software was required to collect the following data and information:

- web noise;

- social noise;

- sentiment analysis;

- social reputation index;

- Brand value.

The amount of data about noise and valence with sentiment analysis that was collected seemed to be enough to answer the hypothesis. 
Online observation, after collecting data from 19236 different messages in more than 80 social network sites (in August 2011), was conducted in one day to be comparable (this information refers data that was gathered and tracked in real time that might change on a daily basis). This was accomplished within the time range of the SMR index (where the numbers from the last month were compared to the previous three months in order to apply a topical adjustment).

Thanks to this selection, different steps of analysis were undertaken to identify:

1) online social noise, quantified in terms of the number of mentions related to a specific brand and related to the total amount of web mentions about this brand;

2) valence trend of customer mentions for each brand, which could be positive, negative or neutral;

3) Social Media Reputation Index (SMR) and Brand value relationship through correlation and regression analysis;

4) a ranking on the basis of these elements, by comparing it to the SMR index and Interbrand ranking.

The first index that was calculated was social noise over web noise (S/W ratio).

After that, correlation and linear regression analysis were conducted with $\mathrm{R}$ software. The main correlations were between:

- $\quad$ positive comments and total social noise, $\operatorname{corr}($ pos, tot $)$;

- negative comments and total social noise, $\operatorname{corr}($ neg,tot);

- neutral comments and total social noise, $\operatorname{corr}($ neu,tot).

In addition, we analysed, through a regression analysis, the relationship between:

- SMR and brand value ranking, $s m r=\beta 0+\beta 1$ value;

- brand value ranking and SMR, value $=\beta 0+\beta 1 \mathrm{smr}$.

Finally, all this information was interpreted crossing the C-Radar and Prism Analysis table concepts.

\section{Findings and discussion}

The main findings that arose from the data analysis allow us to answer the research hypotheses:

- $\mathrm{H}_{1}$ : "Noise": "A social noise (SN) around a brand is related to the total amount of web signals (WN, Web Noise) around the brand".

The first hypothesis about social "Noise" $\left(\mathrm{H}_{1}\right)$, specifically related to its relation to the total amount of brand web signals, is not supported by the study. This result has a significant implication for firm decisions, as there is no correlation between total web noise and amount of social noise in this data analysis. The Social/Web ratio, which is able to track the impact of social consumers noise on total web communication around a specific brand, showed that only $30 \%$ of brands registered a significant loud noise $\mathrm{SN} / \mathrm{WN}>0.2$ (with a social noise that is at least $20 \%$ of the total web noise) (see Appendix 2). This means that the assumption saying that "when a brand has high visibility online it is also a social brand" is not always true. 
The $C$-Radar, as a Social/Web ratio, shows its role to steer practitioners to consider or not consider the auditing of social network conversations. It may suggest to simply enhance web noise or to invest more in social network stimulation in order to become more "social" if the strategy requires it.

- $\mathrm{H}_{2}$ "Valence": The social noise about a brand is mostly constituted by positive $\left(H_{2.1}\right)$ or negative $\left(H_{2.2}\right)$ comments of extremely satisfied or unsatisfied consumers/participants; and/or the neutral rebound activity generates less SN compared to the ones related to positive or negative WOM activity $\left(H_{2.3}\right)$.

In exploring the results related to the $\mathrm{H}_{2}$ about "valence", and investigating whether the majority of brand noise in social networks is composed by positive or negative WOM, our data showed that both $H_{2.1}$ and $H_{2.2}$ are not supported. Indeed, there is no correlation between positive messages and total social noise $(r=0.08)$. More specifically, it is not confirmed that the greater the social noise around a brand is, the more its messages are positive (WOM positive issued). The same result was obtained for negative Word of Mouth $(r=0.05)$. This finding may open new doubts to researchers and practitioners because they frequently measure social network feedback on the basis of positive attitudes of participants (i.e. in terms of the number of "likes", "fun", and "engagement rates"), or monitor negative reactions, while this study suggests that most social network posts are neither positive nor negative (see Appendix 2).

Another important finding for neutral WOM is related to the total amount of social noise, for which there is a strong correlation $(r=0,9012)$. For this reason $\mathrm{H}_{2.3}$ is supported. It highlights that most online messages represent a stimuli that either rebounds the company's activity or does not explain satisfaction or dissatisfaction with a brand.

By analyzing this finding through the Prism Analysis table, it can be seen that the highest percentage of online comments lies in the middle row of the table (neutral), where communication strategies should be focused on maintaining control or ordinary management. As a consequence, there are important marketing implications, as a brand should not merely stimulate the production of new messages, but enhance rebound activity.

- $\mathrm{H}_{3}$ "Value": The brand's social reputation is strictly related to the brand's value $\left(H_{3.1}\right)$; and vice versa $\left(H_{3.2}\right)$.

Finally, in order to verify the third hypothesis, a linear regression was calculated to verify if there was a statistically significant relationship between brand value and social brand reputation $\left(H_{3.1-2}\right)$. The linear regression showed that the social brand reputation ( $r e p=S M R$ index) had a positive impact on the brand value (brand) but the coefficient was not statistically significant (Beta=0.1862626). The same results were obtained by using social brand reputation as a dependent variable. This means that there was not a significant relationship between the two variables $\left(\mathrm{H}_{3}=\mathrm{Not}\right.$ 
supported). In addition, the correlation was weak but positive $(r$ brand,rep $)=0.1862626)$. Nevertheless, a lack of a significant dependence does not mean randomless relationship, as all top 50 SMR index brands belong to the top 100 brand value ranking too (See Appendix 1). The fact that they are valuable brands allows them to be more known and more social; being socially shared in online communities might have an impact in some way on brand value.

\section{Conclusions, implications and limitations}

The main goal of this paper was to better understand the social noise surrounding a brand and its valence in order to offer a contribution to corporate communication audits in e-contexts and validate some of its tools ( $C$-Radar and one side of the Prism Analysis table). The findings point out the critical impact of new signals on the main corporate decision making processes. A marketing audit approach, which considers both consumers' and marketers' web 2.0 communication, is now available for marketing strategies. Although companies are aware that e-relationship networks are complex to manage, they should start measuring their Social/Web ratio, as well as the C-Radar, in order to understand when sentiment and content analysis are required, and to actively track their consumers' communities. Through the use of the Prism Analysis table, communication managers will be able to better understand the nature of external online flows. Companies could begin to understand the social sentiment on their brand, as well as track the existence of any effects of these consumers' communication flows.

This exercise not only allows the identification of distorted or enhanced messages, but also let pay more attention to the "neutral" row in the Prism Analysis table, because neutral rebound flows are more frequent than positive and negative ones.

Our findings might be relevant at a theoretical level, providing a framework for communication audit analyses that include social network messages. Moreover, as an academic implication, we underline that the debate in the literature has often focused on the extreme edges of WOM (highly positive or negative) without considering neutral messages, which represent the majority of online social messages. It is important to listen to these messages and control them in order to have a wide view of external players such as consumers and stakeholders at large. The Prism Analysis table is helpful to understand the impact of external communication signals and players. A company needs to understand the source of its own brand equity and social reputation; the study showed that being a valuable brand allows a company to be more known and social, and, being socially shared in social networks, impacts the brand value to some extent.

Some research limitations require to be explained: first of all, the potential software biased errors (misinterpretation of key words, coexistence of persons/slangs/common words that are similar to the brand name) are very difficult to remove completely, so we carefully worked to clean the data. Another limitation, 
related to one-shot observation timing, is compensated by the large sample that allowed our hypothesis testing to reach the point of saturation. In order to validate the research realized in 2011, we collected further data in 2012, in which we registered very limited differences. The analytic comparison of these two years of analysis will be done in our future study. Moreover, results may be compared over time and across industries to measure whether there will be some changes or trends.

Further research should be done to complete the analysis: we suggest to better explore whether a neutral message represents a repetition/rebound of a firm's communication, or reports an independent message by customers.

Furthermore, further research should be done towards a more comprehensive use of the Prism Analysis table by adopting a content analysis method, particularly in relation to the supply side (columns of Fig. 1).

In addition, the demand side could be better explained through a netnography approach in order to analyse the behaviour of different clusters of users.

Finally, in testing the demand side of the Prism Analysis table, we noticed that the literature often distinguishes between demand and supply side in WOM activity. However, as may be understood from this study, there is a complex mix of roles between senders and receivers that cannot be studied in a separate way. A survey on passive receivers (investigating those who are only on the demand side and are never senders) would be useful to fill this research gap. At the moment, the Prism Analysis table provides results matching content and sentiment analysis, despite the role assumed by consumers in the social e-context.

Our contribution to the theory of corporate communication strategy wants to highlight that external communication signals must be considered when social noise is very loud and represent communication flows that are not under the firm's influence and control most of the time. Such external communication activity might represent a risk for companies but, if listened to, an opportunity as well. To conclude, company communication audits should integrate these signals through the definition of a social media strategy that could include activities such as $\mathrm{C} 2 \mathrm{C}$ reporting, listening to, and monitoring online consumers' signals (without actively intervening in these contexts). 
Appendix 1. The research sample with SMR and Interbrand rankings

\begin{tabular}{|c|c|c|c|}
\hline $\begin{array}{c}\text { SMR } \\
\text { index } \\
\text { ranking } \\
2011\end{array}$ & $\begin{array}{c}\text { Brand } \\
\text { value } \\
\text { ranking } \\
2011\end{array}$ & Brand & Industry \\
\hline 1 & 43 & Ebay & online service \\
\hline 2 & 17 & Apple & technology \\
\hline 3 & 4 & Google & online service \\
\hline 4 & 54 & Blackberry & technology \\
\hline 5 & 36 & Amazon & online service \\
\hline 6 & 44 & Gucci & retail \\
\hline 7 & 50 & Ford & auto \\
\hline 8 & 55 & MTV & entertainment \\
\hline 9 & 19 & Samsung & technology \\
\hline 10 & 66 & Yahoo! & online service \\
\hline 11 & 8 & Nokia & technology \\
\hline 12 & 41 & Dell & technology \\
\hline 13 & 3 & Microsoft & technology \\
\hline 14 & 9 & Disney & entertainment \\
\hline 15 & 38 & Nintendo & technology \\
\hline 16 & 11 & Toyota & auto \\
\hline 17 & 97 & Starbucks & $\begin{array}{l}\text { food and } \\
\text { drink }\end{array}$ \\
\hline 18 & 20 & Honda & auto \\
\hline 19 & 34 & Sony & technology \\
\hline 20 & 91 & Ferrari & auto \\
\hline 21 & 65 & Hyundai & auto \\
\hline 22 & 25 & Nike & retail \\
\hline 23 & 2 & IBM & technology \\
\hline 24 & 1 & Coca-Cola & $\begin{array}{l}\text { food and } \\
\text { drink }\end{array}$ \\
\hline 25 & 6 & $\begin{array}{l}\text { Mc } \\
\text { Donald's }\end{array}$ & $\begin{array}{l}\text { food and } \\
\text { drink }\end{array}$ \\
\hline
\end{tabular}

\begin{tabular}{|c|c|c|c|}
\hline $\begin{array}{c}\text { SMR } \\
\text { index } \\
\text { ranking } \\
2011 \\
\end{array}$ & $\begin{array}{c}\text { Brand } \\
\text { value } \\
\text { ranking } \\
2011\end{array}$ & Brand & Industry \\
\hline 26 & 88 & Adobe & technology \\
\hline 27 & 10 & $\mathrm{HP}$ & technology \\
\hline 28 & 12 & $\begin{array}{l}\text { Mercedes- } \\
\text { Benz }\end{array}$ & auto \\
\hline 29 & 23 & Pepsi & $\begin{array}{l}\text { food and } \\
\text { drink }\end{array}$ \\
\hline 30 & 98 & $\begin{array}{l}\text { Harley- } \\
\text { Davidson }\end{array}$ & auto \\
\hline 31 & 100 & Burberry & retail \\
\hline 32 & 15 & BMW & auto \\
\hline 33 & 63 & Audi & auto \\
\hline 34 & 7 & Intel & technology \\
\hline 35 & 33 & Canon & technology \\
\hline 36 & 73 & Panasonic & technology \\
\hline 37 & 53 & Volkswagen & auto \\
\hline 38 & 24 & $\begin{array}{l}\text { American } \\
\text { Express }\end{array}$ & financial \\
\hline 39 & 72 & Porsche & auto \\
\hline 40 & 62 & Adidas & retail \\
\hline 41 & 48 & Zara & retail \\
\hline 42 & 46 & Heinz & $\begin{array}{l}\text { food and } \\
\text { drink }\end{array}$ \\
\hline 43 & 28 & Ikea & retail \\
\hline 44 & 13 & Gillette & $\begin{array}{l}\text { health and } \\
\text { beauty }\end{array}$ \\
\hline 45 & 89 & Smirnoff & $\begin{array}{l}\text { food and } \\
\text { drink }\end{array}$ \\
\hline 46 & 77 & Cartier & retail \\
\hline 47 & 16 & $\begin{array}{l}\text { Louis } \\
\text { Vuitton }\end{array}$ & retail \\
\hline 48 & 45 & L'oreal & $\begin{array}{l}\text { health and } \\
\text { beauty }\end{array}$ \\
\hline 49 & 85 & Corona & $\begin{array}{l}\text { food and } \\
\text { drink }\end{array}$ \\
\hline 50 & 82 & Visa & financial \\
\hline
\end{tabular}


Appendix 2. Sentiment analysis of 50 brands (Aug. 2011)

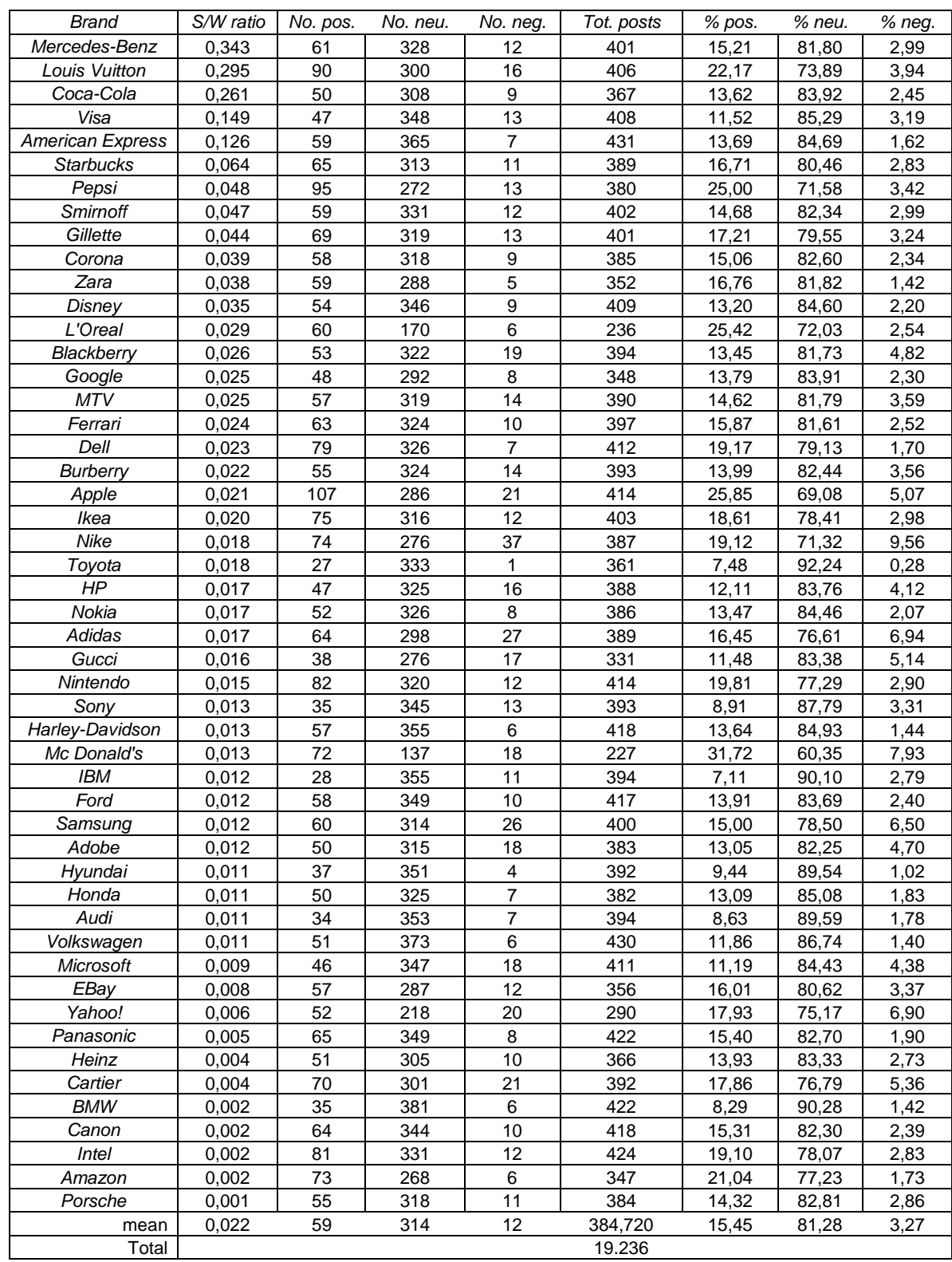




\section{References}

ARNDT J. (1967), "The role of product-related conversations in the diffusion of a new product", Journal of Marketing Research, August, vol. 4, n. 3, pp. 291-295.

ARNOULD E.J., PRICE L.L. (1993), "River magic: Extraordinary experience and the extended service encounter", Journal of Consumer Research, vol. 20, pp. 24-45.

BELK R. (2010), "Sharing”, Journal of Consumer Research, vol. 36, n. 5, pp. 715-734.

BETTENCOURT L. (1997), "Customer voluntary performance: Customers as partners in service delivery", Journal of Retailing, vol. 73, n. 3, pp. 383-407.

BRADDOCK R. (1958), “An extension of Lasswell formula”, Journal of Communication vol. 8, n. 2, pp. 88-93

BROWNLIE D.T. (1993), “The Marketing Audit: A Metrology and Explanation”, Marketing Intelligence \& Planning, vol. 11, n. 1.

BUTTLE F. (1998), "Word of mouth: understanding and managing referral marketing", Journal of strategic marketing, vol. 6, n.3, pp. 241-254.

CAMUS B. (1988), Audit marketing, Les éditions d'organisation, Paris.

CHATTERJEE P. (2001), "Online review: do consumers use them?", Advances in Consumer Research, vol. 28, pp. 129-133.

CHEN Y., XIE J. (2008), "Online consumer review: word-of-mouth as a new element of marketing communication mix", Management Science, vol. 54, n. 3, pp. 477-491.

CHERUBINI S. (1988), Marketing Audit, Utet, Torino.

CHEVALIER J., MAYZLIN D. (2006), "The Effect of Word of Mouth on Sales: Online Book Reviews", Journal of Marketing Research, vol. 43 (August), pp. 345-354.

CLARK T., MARTIN C.L. (1996), Customer-to-customer: The forgotten relationship in marketing, in Iacobucci D. (Ed. ), Networks in Marketing, Thousand Oaks, CA: Sage.

CONFENTE I. (2011), "Word of Mouth in the tourism industry: an empirical investigation of Service experience", Proceedings $14^{\text {th }}$ Toulon-Verona/ICQSS Conference "Excellence in services" at the University of Alicante, Spain.

CONFENTE I. (2012), Il Word of Mouth: l'evoluzione del comportamento del consumatore nell'era digitale, Giuffrè Editore, Milano.

COVA B., DALLI D. (2009) "Working Consumers: The Next Step in Marketing Theory?", Marketing Theory, vol. 9, n. 3, pp. 315-339.

CUGINI A., WILSON R.M.S. (2005), Marketing e controllo, Egea, Milano.

DE BRUYN A., LILIEN G.L. (2008), "A Multi-Stage Model of Word of Mouth Through Viral Marketing," International Journal of Research in Marketing, vol. 25, n. 3, pp. 143-225.

DE CHIARA A. (2009), "Knowledge co-creation in online stakeholders relationships", Sinergie Quaderni, n. 6, pp. 169-192.

DEIGHTON J. (2002), "How snapple got its juice back", Harvard Business Review, vol. 8, n. 1, pp. 47-53.

DELLAROCAS C. (2003), "The Digitization of Word of Mouth: Promise and Challenges of Online Feedback Mechanisms", Management Science, vol. 49, n. 10, pp. 1401-1424.

DELLAROCAS, C. (2006), "Strategic manipulation of internet opinion forums: implications for consumers and firms", Management Science, vol. 52, n. 10, pp. 1577-1593.

FOGG C.D. (1985), Diagnostic Marketing: Finding and Fixing Critical Problems, Addison Wesley Publishing Co., Addison-Wesley, Reading, MA.

FOULGER D. (2004), Models of Communication Process, http://davis.foulger.info/research/unifiedModelOfComunication.htm, February 25, Brooklyn College, CUNY. 
FOURNIER S. (1999), "Consumers and their brands: developing relationship theory in consumer research", Journal of Consumer Research, vol. 24, pp. 343-373.

GODES D., MAYZLIN D. (2004), "Using Online Conversations to Study Word-of-Mouth Communication", Marketing Science, vol. 23, n. 4, p. 545-560.

GOLDHABER G., KRIVONOS P. (1977), "The ICA Communication Audit: Process, status, critique". The Journal of Business Communication, vol. 15, n. 1, pp. 41-55.

GOLDSMITH R.E., HOROWITZ D. (2006), "Measuring motivations for online opinion seeking", Journal of Interactive Advertising, vol. 6, n. 2, pp. 1-16.

GROVE S.J., FISK R.P. (1997), "The impact of other customers on service experiences: A critical incident examination of 'getting along'”, Journal of Retailing, vol. 73, n. 1, pp. 63-86.

HARGIE O., TOURISH D. (2000), Handbook of communication audits for Organizations, Routledge, London.

HENNIG-THURAU T., GWINNER K.P., WALSH G., GREMLER D.D. (2004), "Electronic word-of-mouth via consumer-opinion platforms: what motivates consumers to articulate themselves on the internet?", Journal of interactive marketing, vol. 18, n. 1, pp. 38-52.

HOGARD E., ELLIS R. (2006), "Evaluation and communication - Using a communication audit to evaluate organizational communication", Evaluation review, vol. 30, n. 2, pp. 171-187.

HOLLENBECK CANDICE R., ZINKHAN G.M. (2010), "Anti-brand Communities, Negotiation of Brand Meaning, and the Learning Process: The Case of Wal-Mart", Consumption, Markets \& Culture, vol. 13, n. 3, pp. 325-345.

HOLT D.B. (2004) How Brands Become Icons: The Principles of Cultural Branding, Cambridge MA: HBS Press. in: Cova B., Pace S., (2006), Brand community of convenience products: new forms of customer empowerment- the case of "my Nutella the community, European Journal of Marketing, vol. 40, n. 9, pp. 1087-1105.

HU S.M., WINER R.S., ASSAEL H., CHEN X. (2012), "An Empirical Study of Word-ofMouth Generation and Consumption", Marketing Science, vol. 31, n. 6, pp. 952-963.

KOTLER P., GREGOR W., RODGERS W.H. (1977), "The Marketing Audit Comes of Age", Sloan Management Review, vol. 18, n. 2, pp. 25-43.

KOZINETS R.V, HANDELMAN J.M. (2004), "Adversaries of Consumption: Consumer Movements, Activism, and Ideology”, Journal of Consumer Research, vol. 31, n. 3, pp. 691-704.

KOZINETS R.V., HANDELMAN J.M., LEE M.S.W. (2010),’Don't Read This; or, Who Cares What the Hell Anti-Consumption Is, Anyways?", Consumption Markets \& Culture, vol. 13, n. 3, pp. 225-233.

LASSWELL H.D. (1948), "The Structure and Function of Communication Society", in Bryson L., The Communication of Ideas, Harper, New York.

LAU G.T., NG S. (2001),'Individual and situational factors influencing negative word of mouth behaviour", Canadian Journal of Administrative sciences, vol. 18, n. 3, pp. 163-178.

LEE S., HWANG T., LEE H.L. (2006), "Corporate blogging strategies of the Fortune 500 companies", Management Decision, vol. 44, n. 3, pp. 315-334.

LIU Y. (2006),"Word of Mouth for Movies: Its Dynamics and Impact on Box Office Revenue", Journal of Marketing, vol. 70 (July), pp. 74-89.

LOWE W. (2003), Content Analysis Software: A Review Technical Report for the Identity Project, Weatherhead Center for International Affairs, Harvard University, Boston.

MARTIN C.L., PRANTER C.A. (1989), “Compatibility management: Customer-to-customer 
relationships in service environments", The Journal of Services Marketing, vol. 3, n. 3, pp. 5-15.

MCDONALD M.H.B., LEPPARD J.W. (1991), The marketing audit: translating marketing theory into practice, Butterworth-Heinemann, Oxford, UK.

MILLER T.W. (2005), Data and Text Mining: a business applications approach, Pearson, Upper Saddle River, NJ.

MOHR J.J., NEVIN J.R. (1990), "Communication strategies in marketing channels: A theoretical perspective", Journal of Marketing, vol. 54, n. 4, pp. 36-51.

NOBLE C.H., SINHA R.K., KUMAR A. (2002),"Market orientation and alternative strategic orientations: A longitudinal assessment of performance implications", Journal of Marketing, vol. 66, n. 4, pp. 25-39.

O'GUINN T.C., MUNIZ A.M. Jr. (2005),'Communal consumption and the brand", in Mick D.G., Ratneshwar S., Consumption: Frontiers of Research on Consumer Motives, Routledge, London, pp. 252-272.

OXENFELDT A.R. (1959), "The Marketing Audit: Its Nature, Purposes and Problems, Analyzing and Improving Marketing Performance", American Management Association Report, vol. 32, p. 25.

PRAHALAD C.K., RAMASWAMY V. (2000),'Co-opting customer competence", Harvard Business Review, vol. 78, n. 1, pp. 79-88.

SCHIFFMAN L.G., KANUK L.L. (1995), "Consumer Behaviour, 9th Ed. NJ: Upper Saddle River", Prentice Hall, in Brown J., Broderick A.J., Lee N. (2007), "Word of Mouth communication within online communities: conceptualizing the online social network", Journal of Interactive Marketing, vol. 21, n. 3, pp. 2-20.

SCHINDLER R.M., BICKART B. (2005), "Published word of mouth: Referable, consumergenerated information on the Internet", Online consumer psychology: Understanding and influencing consumer behavior in the virtual world, pp. 35-61.

SEN S., LERMAN D. (2007), "Why are you telling me this? An examination into negative consumer reviews on the Web", Journal of Interactive Marketing, vol. 21, n. 4, pp. 76-94

SHANNON C.E. (1948), “A mathematical theory of communication”, Bell System Technical Journal, vol. 4, pp. 379-423.

SHANNON C.E., WEAVER W. (1949), The Mathematical Theory of Communication, University of Illinois Press, Trad. it., (1971) La Teoria Matematica della Comunicazione, Etas Kompass, Milano.

SIGNORI P. (2008), Visioni, percorsi e verifiche nei controlli manageriali. Applicazioni al marketing e alla comunicazione, McGraw-Hill, Milano.

SIGNORI P., CONFENTE I. (2011), "L'impatto delle comunità virtuali sul processo di comunicazione aziendale. Nuovi strumenti per il controllo", Atti X International Marketing Trends Conference, ESCP, Paris.

STERN M.E. (1972), La programmazione del marketing, Isedi, Milano.

TRUSOV M., BUCKLIN R.E., PAUWELS K. (2009), "Effects of word-of-mouth versus traditional marketing: findings from an internet social networking site", Journal of marketing, vol. 73, pp. 90-102.

VESCOVI T. (2008), "I clienti invadenti e il marketing non convenzionale", Micro\&Macro Marketing, vol. 17, n. 3, pp. 449-454.

VESCOVI T. (2009), "Invading customers and business governance", Sinergie Quaderni, n 16 , pp. 67-83.

WEINER N. (1948), Cybernetics: or Control and Communication in the Animal and the Machine, Wiley, New York. 
WEINER N. (1986), Human Use of Human Beings: Cybernetics and Society, Da Capo Press, Boston.

WILSON A. (1982), Marketing Audit Checklist, McGraw Hill, London.

WILSON A. (2002), The Marketing Audit textbook, Koogan Page, London.

WIPPERFURTH A. (2005), Brand Hijack: Marketing Without Marketing, New York, NY:Portfolio, in Addis M., Podestà S. (2005), "Long life to marketing research: a postmodern view”, European Journal of Marketing, vol. 39, n. 3-4, pp. 386-412. 
